\title{
OXCT1 wt Allele
}

National Cancer Institute

\section{Source}

National Cancer Institute. OXCT1 wt Allele. NCI Thesaurus. Code C158469.

Human OXCT 1 wild-type allele is located in the vicinity of 5 p13.1 and is approximately 141 $\mathrm{kb}$ in length. This allele, which encodes succinyl-CoA:3-ketoacid coenzyme A transferase 1 , mitochondrial protein, is involved in ketone body metabolism. Loss of function mutations in the gene are associated with succinyl-CoA:3-oxoacid-CoA transferase deficiency (SCOTD). 